\title{
Studies on autoimmunity for initiation of Beta-cell destruction VIII. Pancreatic Beta-cell dependent autoantibody to a 38 kilodalton protein precedes the clinical onset of diabetes in BB rats
}

\author{
I. Y. Ko ${ }^{1,2}$, S.H. Ihm ${ }^{1,2}$ and J. W. Yoon ${ }^{1,2}$ \\ ${ }^{1}$ Laboratory of Viral and Immunopathogenesis of Diabetes, Julia McFarlane Diabetes Research Centre, and ${ }^{2}$ Division of Virology, \\ Department of Microbiology and Infectious Diseases, Faculty of Medicine, The University of Calgary, Calgary, Alberta, Canada
}

\begin{abstract}
Summary. Autoantibody to a rat islet cell-protein of 38 kilodalton was detectable at around 30 days of age in the sera of diabetes-prone Biobreeding (DP-BB) rats by both immunoprecipitation and differential Western blotting methods. Anti-38 kilodalton islet cell autoantibody was not, however, observed in the sera from 5- to 20-day-old DP-BB rats. Over $90 \%$ of DP-BB rats in which the antibody was detected, eventually developed Type 1 (insulin-dependent) diabetes mellitus. The antibody disappeared within 2 weeks after diabetes onset. However, it was preserved in the sera of DP$\mathrm{BB}$ rats which had been treated with silica to prevent insulitis. The anti-38 kilodalton islet cell autoantibody was not detected in sera from control Wistar Furth (WF) rats. The autoantibody also cross-reacted with a rat insulinoma (RINm5F) cell protein of 38 kilodalton, but did not react with protein from mouse fibroblast (L-929 cells), rat pituitary cells (GH3
\end{abstract}

cells), or normal rat lymphocytes. The production of the autoantibody appears to be pancreatic Beta-cell dependent, since the autoantibody disappears after almost complete depletion of Beta cells, but is consistently present as long as Beta cells remain. Identification of the Beta-cell dependent anti-38 kilodalton islet cell autoantibody, which cross-reacts with a rat insulinoma cell protein of 38 kilodalton and precedes the onset of Type 1 diabetes in BB rats, will be invaluable for study of the molecular nature of a target islet cell autoantigen associated with the induction of autoimmunity in DP-BB rats.

Key words: Diabetes-prone $\mathrm{BB}$ rats, $38 \mathrm{kD}$ islet cell autoantibody, prediction of Type 1 (insulin-dependent) diabetes mellitus, immunoprecipitation, differential Western blotting.
Type 1 (insulin-dependent) diabetes mellitus is the consequence of progressive Beta-cell destruction during an asymptomatic period often extending over many years [1]. Current concepts incriminate genetically predetermined, autoimmune-mediated Beta-cell destructive mechanisms in the pathogenesis of Type 1 diabetes $[2,3]$. One piece of evidence supporting the aetiologic role of islet Beta-cell specific autoimmunity is the presence of circulating islet cell autoantibodies including islet cell antibodies (ICA), islet cell surface antibodies (ICSA), and insulin autoantibodies (IAA) [4, 5]. Recently, Type 1 diabetes in humans was characterized by the presence of an autoantibody directed against an immunoprecipitable 64-kilodalton $(64 \mathrm{kD})$ islet cell protein [6, 7]. The anti-64 $\mathrm{kD}$ antibody is detectable during the early, pre-clinical phase of Type 1 diabetes, several years before the development of diabetes [7]. This premonitory autoimmune response is difficult to study in humans, since susceptible individuals are not easily identified. Fortunately, BioBreeding (BB) rats, which spontaneously develop a diabetic syndrome that in many respects resembles human Type 1 diabetes, contain antibodies to a $64 \mathrm{kD}$ rat islet cell protein [8]. The finding of anti-64 kD islet cell autoantibodies in $\mathrm{BB}$ rats renders possible an in-depth predictive study on the development of diabetes. However, these antibodies cannot be detected by the Western blotting method. In recent immunoprecipitation studies, Holmes et al. were unable to show evidence of surface expression of the native $64 \mathrm{kD}$ protein of human islet cells [9].

In addition to the anti-64 $\mathrm{kD}$ islet cell antibodies, sera from four of four tested newly onset Type 1 diabetic patients immunoprecipated a $38 \mathrm{kD}$ islet cell protein prepared from HLA-DR3-positive donor islets [6]. To date, no information is available on an autoantibody against a $38 \mathrm{kD}$ islet cell protein in DP-BB rats. This investigation was initiated to determine whether an anti- $38 \mathrm{kD}$ islet cell antibody is present in DP-BB rats, and whether this antibody precedes the clinical onset of Type 1 diabetes. In addition, this study was designed to determine whether this antibody can be detected using both primary pancreatic islet cells and cultured RINm5F cells, by both immunoprecipitation and differential Western blotting methods. 
Such an autoantibody would be of great advantage in studying the nature of the autoantigen at the molecular level, since there may be a common antigenic determinant (to the islet cell autoantibody) between rat islet cells and RINm5F cells.

\section{Materials and methodls}

\section{Animals}

Our BB rat colony was produced from a breeding stock purchased from the University of Massachusetts, (Worchester, Mass., USA). These animals were maintained on regular rat chow and tap water ad libitum at the University of Calgary. Beginning at about 50 days of age, urinary glucose and ketone levels were determined twice weekly with Diastix and Ketostix reagent strips (Miles, Ontario, Canada) [10]. Individual rats were classified as diabetic on the basis of persistent positive glycosuria [11]. The overall incidence of diabetes among the colony was approximately $80 \%$ and the mean age at detection of diabetes was 95 days (range: 70-110 days). A total of 138 DP-BB rats (several different ages) were used for this study. In addition, 45 Wistar Furth (WF) rats were purchased from the Harlan-Sprague-Dawley Laboratory (Indianapolis, Ind., USA), and 20 Lewis rats and 20 Sprague-Dawley rats were purchased from the Charles River Laboratory (St. Constant, Quebec, Canada).

\section{Silica administration}

One group of DP-BB rats (13 rats) received silica (Steinkohle-Bergbau-Verein, Essen, FRG), for prevention of diabetes, at a dose of $100 \mathrm{mg} / \mathrm{kg}$ body weight, intraperitoneally, every 10 days from 40 to 110 days of age $[11,12]$. One group of Wistar Furth rats (10 rats) received the same treatment.

\section{Cell cultures}

Rat insulinoma cells (RINm5F) were grown in RPMI-1640 medium supplemented with $10 \%$ fetal bovine serum (FBS), $20 \mathrm{mmol} / \mathrm{l}$ HEPES, $2 \mathrm{mmol} / \mathrm{l}$ glutamine and $50 \mu \mathrm{g} / \mathrm{ml}$ gentamicin. Rat pituitary tumour cells (GH3, ATCC CCL 82.1), which secreted somatotrophin, were grown in Ham's F-10 medium containing $20 \%$ fetal bovine serum and $50 \mu \mathrm{g} / \mathrm{ml}$ gentamicin. Mouse fibroblasts (L-929 cells) were cultured as described elsewhere [13]. Splenic lymphocytes were isolated from WF rats as described elsewhere [14]. All cells were subcultured at 3 -day intervals and maintained at $37^{\circ} \mathrm{C}$ in a $5 \%$ $\mathrm{CO}_{2}$ atmosphere.

\section{Pancreatic islets}

Pancreatic rat islets were isolated by a modification of the collagenase digestion-ficoll gradient method $[15,16]$. Briefly, the pancreas was injected with collagenase solution (Worthington type IV collagenase, $1.1 \mathrm{mg} / \mathrm{ml}$ in Krebs-Henseleit-bicarbonate buffer, $\mathrm{pH} 7.4$ ) through the common bile duct. The pancreas was then dispersed by aspiration with a Pasteur pipette. Following ficoll gradient centrifugation, the islets were hand-picked under the stereomicroscope and maintained in RPMI-1640 medium until used.

\section{Metabolic labelling and immunoprecipitation}

Metabolic labelling and immunoprecipitation were performed in a similar manner to that described elsewhere $[6,8]$. Islets $(500)$, RINm5F cells $\left(2 \times 10^{7}\right)$, L-929 cells $\left(2 \times 10^{7}\right)$, GH3 cells $\left(2 \times 10^{7}\right)$ or rat lymphocytes $\left(2 \times 10^{7}\right)$ were washed three times with serum-free RPMI-1640 medium. The cells were then labelled by incubation for $12 \mathrm{~h}$ in RPMI-1640 labelling medium supplemented with 5\% dia- lysed fetal bovine serum and $0.5 \mathrm{mCi}$ of ${ }^{35} \mathrm{~S}$-methionine (ICN, $>800 \mathrm{mCi} / \mathrm{mmol}$ ). Following labelling, cells were washed three times with calcium magnesium-free phosphate buffered saline (CMF-PBS) containing $2 \mathrm{mmol} / \mathrm{l}$ cold methionine (Sigma, St. Louis, Mo, USA). Cell lysis was performed at $4{ }^{\circ} \mathrm{C}$ for $1 \mathrm{~h}$ in $20 \mathrm{mmol} / \mathrm{l} \mathrm{Tris}$ buffer ( $\mathrm{pH}$ 7.4) containing 1000 kallikrein inhibitory units/ml aprotinin, $2 \mathrm{mmol} / 1$ phenylmethylsulphonyl fluoride, $5 \mathrm{mmol} / \mathrm{l} \mathrm{EDTA}$, $5 \mathrm{mmol} / \mathrm{l}$ iodoacetamide, $150 \mathrm{mmol} / \mathrm{NaCl}$, and $1 \% \mathrm{NP}-40$. Insoluble materials were removed by ultracentrifugation at $100000 \times \mathrm{g}$ for $30 \mathrm{~min}$. The metabolically labelled cell lysates were then precleared with pooled control Wistar Furth rat sera (10:1 ratio) at $4^{\circ} \mathrm{C}$ for $5 \mathrm{~h}$, followed by absorption to $100 \mu \mathrm{l}$ of protein A sepharose CL$4 \mathrm{~B}$ (Pharmacia, Uppsala, Sweden) for $2 \mathrm{~h}$ at $4^{\circ} \mathrm{C}$. The immune complexes were separated by centrifugation for 5 min at $2000 \times g$. Aliquots $(250 \mu \mathrm{l})$ of the precleared lysates were incubated with $20 \mu \mathrm{l}$ of sera from individual rats from each of the rat groups overnight at $4^{\circ} \mathrm{C}$. To each tube, $100 \mu \mathrm{l}$ of protein A sepharose CL-4B suspension was added, and the mixture was incubated for $2 \mathrm{~h}$ at $4^{\circ} \mathrm{C}$. The mixture was then washed three times by centrifugation with $20 \mathrm{mmol} / \mathrm{l}$ Tris ( $\mathrm{pH} 7.4$ ) containing $0.5 \% \mathrm{NP}-40$ and $150 \mathrm{mmol} / \mathrm{NaCl}$. Bound immune complexes were denatured in buffer containing $62.5 \mathrm{mmol} / 1$ Tris ( $\mathrm{pH} 6.8$ ), $10 \%$ glycerol, $2.5 \%$ SDS, $5 \%$ beta-mercaptoethanol and $0.001 \%$ bromophenol blue. The proteins were analysed by $7.5 \%$ (or $10 \%$ ) discontinuous SDS-polyacrylamide gel electrophoresis, followed by staining with Coomassie brilliant blue G-250. After destaining, the gel was dried and autoradiographed at $-70^{\circ} \mathrm{C}$ for 3 to 5 days using X-Omat diagnostic film (Kodak, XAR-5).

\section{Differential Western blotting}

Crude lysates from RINm5F cells were prepared as described above. The lysates were then separated by $10 \%$ discontinuous SDS-polyacrylamide gel electrophoresis for $6 \mathrm{~h}$ at $25 \mathrm{~mA}$ constant current. Protein concentration was determined with Bio-Rad protein assay kit (Bio-Rad, Richmond, Calif., USA) using bovine serum albumin as a standard. We used three different concentrations of RINm5F cell protein: $1 \mu \mathrm{g}, 5 \mu \mathrm{g}$ and $20 \mu \mathrm{g}$, and found that $20 \mu \mathrm{g}$ of the protein was optimum to obtain visible bands. The protein bands were transferred to nitrocellulose paper ( $\mathrm{S} \& \mathrm{~S}, \mathrm{BA} 83,0.2 \mu \mathrm{m}$, Schleicher and Schuell Inc., Keene, NH, USA) in transfer buffer containing $25 \mathrm{mmol} / \mathrm{l}$ Tris, $92 \mathrm{mmol} / 1$ glycine and $20 \%$ volume/volume (v/v) methanol as described elsewhere [17], with the following modification. Strips of the nitrocellulose paper were first incubated with $3 \%$ BSA in CMF-PBS for $2 \mathrm{~h}$ at room temperature, followed by incubation with pooled control Wistar Furth sera (1:100 dilution) for $5 \mathrm{~h}$ After exhaustive washing with $0.05 \%$ Tween 20 in CMF-PBS, the strips were incubated with unlabelled mouse anti-rat light $(\mathrm{k})$ chain specific monoclonal antibody (MAR 18.5, ATCC TIB 216: ATCC, Rockville, Md, USA) at a final concentration of $50 \mu \mathrm{g} / \mathrm{ml}$ in CMFPBS for $1 \mathrm{~h}$ at room temperature. Following thorough washing, the strips were incubated with the individual sample sera (1:100 dilution) in CMF-PBS for $5 \mathrm{~h}$ at room temperature. The strips were then incubated with alkaline phosphatase conjugated goat anti-rat IgG (H and L chains) (Kirkgard Perry Laboratory, Rockville, Md, USA) at a 1:1000 dilution in CMF-PBS containing 1\% goat serum. After thorough washing, the strips were developed using BCIP/NBT phosphatase substrate system (Bio-Rad, Richmond, Calif., USA) following the manufacture r's protocol.

\section{Histologic examination and immunofluorescence}

At 30 days of age (earliest detection of anti- $38 \mathrm{kD}$ islet cell antibody), 110 days of age (silica administration), and 120 days of age (3 weeks after the onset of diabetes), DP-BB rats were killed and the pancreata were fixed in formalin. Paraffin-embedded sections were stained with haematoxylin and eosin, and examined. Indirect immunofluorescent staining of pancreatic islet sections was performed to detect the presence of insulin-containing Beta cells as described elsewhere $[15,18]$. 


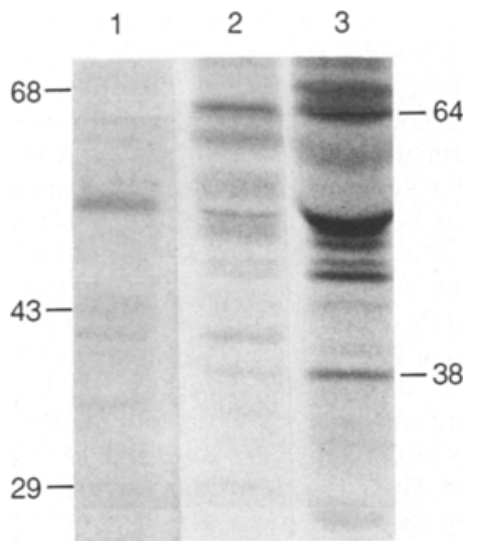

Fig. 1. Autoradiograph of sodium dodecyl sulphate-polyacrylamide gel electrophoresis of immunoprecipitates of WF rat islet cell extracts with control WF rat (75-day-old) sera (lane 1), DP-BB rat (75 day-old) sera (lane 2), and human diabetic anti-64 kilodalton (kD)positive sera (lane 3 ). Metabolically labelled rat islet lysates were pre-cleared with pooled sera from ten-WF rats (30-100 day old), and reacted with individual control (lane 1) and test (lane 2 and 3 ) sera. Equal amounts $(20 \mu \mathrm{l})$ of control sera (lane 1$)$ and test sera (lane 2 and lane 3) were used for immunoprecipitation. Similarly, an equal amount $(80 \mu \mathrm{l})$ of bound immune complex was applied to each lane. Molecular-weight markers are indicated at left. Antigens of $38 \mathrm{kD}$ and $64 \mathrm{kD}$ are indicated by an arrow with appropriate number at right. Lane 1: control WF sera failed to immunoprecipitate $38 \mathrm{kD}$ and $64 \mathrm{kD}$ proteins from islet cell extract. Lane 2 : both $38 \mathrm{kD}$ and $64 \mathrm{kD}$ proteins recognized by sera from DP-BB rat. Lane 3; both $38 \mathrm{kD}$ and $64 \mathrm{kD}$ proteins recognized by sera from a human Type $\mathrm{i}$ (insulin-dependent) diabetic patient

\section{Statistical analysis}

Chis-quare test with Yate's correction [19] was used to calculate $p$-values for statistical comparison between two different groups.

\section{Results}

\section{Detection of antibody against a $38 \mathrm{kD}$ islet cell protein}

Autoantibody to a rat islet cell- or RINm5F cell-protein of $38 \mathrm{kD}$ was found in the sera of DP-BB rats by immunoprecipitation (Fig. 1, lane 2 and Fig. 2, lanes 3, 4 and 6). Anti$38 \mathrm{kD}$ islet cell autoantibody was also found in the sera from a patient with Type 1 diabetes (Fig. 1, lane 3 ). In contrast, the anti-38 $\mathrm{kD}$ islet cell autoantibody was rarely present in the sera of control Wistar Furth rats (Fig. 1, lane 1 and Fig. 2, lane 1 ) or in that of neonatal DP-BB rats (5 days after birth) (Fig. 2, lane 2). Over $90 \%$ (12 of 13) of DP-BB rats contained the anti-38 $\mathrm{kD}$ islet cell autoantibody, whereas only one of 14 age-matched Wistar Furth rats $(7 \%)(p<0.001)$ had the antibody. Antibody to a rat islet cell protein of $64 \mathrm{kD}$ was also found in DP-BB rat serum (Fig. 1, lane 2) and in human diabetic serum (Fig. 1, lane 3). The $38 \mathrm{kD}$ band completely disappeared within 2 weeks after development of the disease (Fig. 2, lane 5), although several other bands $(45 \mathrm{kD}, 55 \mathrm{kD}$, and $74 \mathrm{kD})$ were consistently present in WF control sera and DP-BB rat sera tegardless of age or development of diabetes. To determine whether the disappearance of anti- $38 \mathrm{kD}$ islet cell was con- sistent, we followed-up six acutely diabetic DP-BB rats by treatment with insulin (2 I.u./day, NPH insulin) for up to 5 weeks after the onset of diabetes. Two of the six DP-BB rats showed early disappearance of the $38 \mathrm{kD}$ antibody $(2$ and 5 days after onset). Four animals showed relatively late disappearance of the antibody $(7,7,11$ and 14 days after onset). Within 2 weeks, all of the diabetic rats showed disappearance of the anti-38 kD islet cell antibody. In contrast, the anti-38 kD antibody was continuously detected in the sera of silica-treated DP-BB rats at an age at which untreated rats no longer had the antibody after onset of diabetes (Fig. 2, lane 6). Since silica treatment of DP-BB rats completely prevents the development of insulitis and diabetes [11,12], consistent detection of the autoantibody

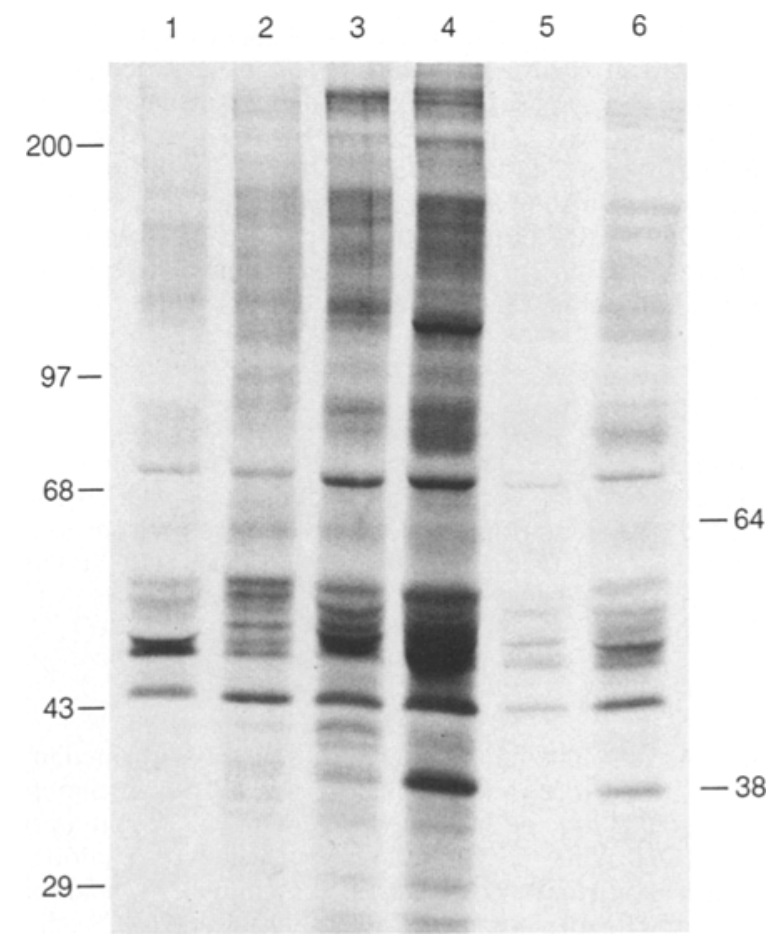

Fig.2. Autoradiograph of sodium dodecyl sulphate-polyacrylamide gel electrophoresis of immunoprecipitates of RINm5F cell proteins with sera from the control WF rat and different ages of DP-BB rats. Metabolically labelled RINm5F cell lysates were pre-cleared with pooled sera from ten WF rats (30-100 day-old), and reacted with individual test sera. Equal amounts $(20 \mu \mathrm{l})$ of control sera (lane 1) and test sera (lane 2 through lane 6 ) were used for immunoprecipitation. Similarly, an equal amount $(80 \mu \mathrm{l})$ of bound immune complex was applied to each lane. Molecular weight markers are indicated at left. Antigens of 38 kilodalton $(\mathrm{kD})$ and $64 \mathrm{kD}$ are indicated by an arrow with appropriate number at right. Lane 1: control WF (110-day-old) sera failed to immunoprecipitate $38 \mathrm{kD}$ protein from RINm5F cell extract. Lane 2: neonate DP-BB rat sera (at 5 days of age) also failed to immunoprecipitate the $38 \mathrm{kD}$ protein. Lane $3: 38 \mathrm{kD}$ protein recognized by sera from 30 -day-old DP-BB rats. Lane $4: 38 \mathrm{kD}$ protein recognized by sera from 75-day-old DP-BB rat. Lane 5:110-day-old diabetic DP-BB rat sera ( 7 days after the onset of diabetes) failed to immunoprecipitate the $38 \mathrm{kD}$ protein. Lane $6: 38 \mathrm{kD}$ protein recognized by sera from 140-day-old DP-BB rat which was treated with silica for the preservation of Beta cells. Control sera (lane 1) and 110-day-old diabetic DP-BB rat sera (lane 5), which does not contain anti-38 kD islet cell antibody, appeared to react less strongly with RINm5F cell proteins. All sera (lane 1 through lane 6) failed to immunoprecipitate $64 \mathrm{kD}$ protein, since the protein extracts were prepared from RINm5F cells $[6,8]$ 


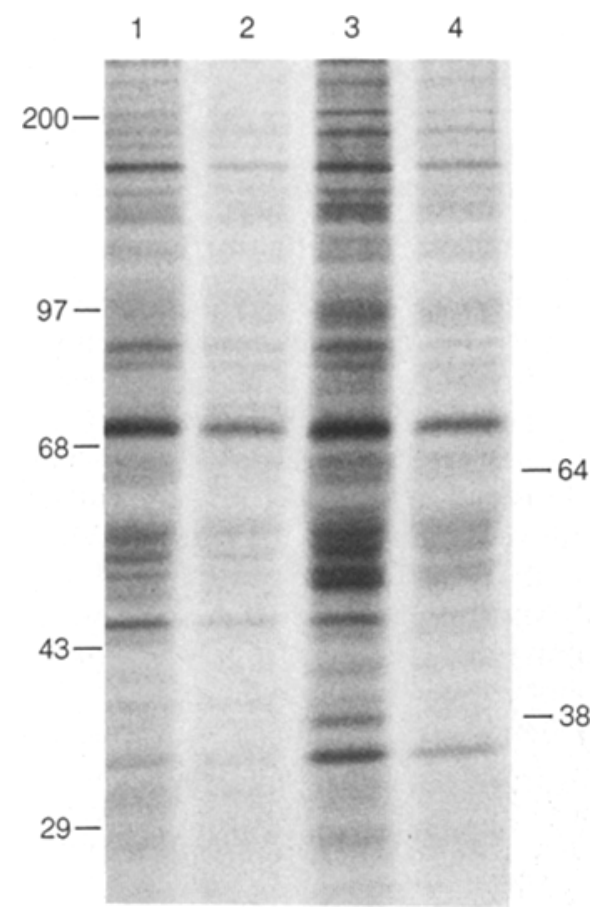

Fig.3. Cell-type specificity of the response to anti-38 kilodalton (kD) autoantibody. Total protein lysates were obtained from L-929 cells (lane 1 ), rat pituitary cells (GH3) (lane 2 ), RINm5F cells (lane 3), and normal WF rat lymphocytes (lane 4). The lysates $(200 \mu \mathrm{l})$ were precleared with $20 \mu \mathrm{l}$ of pooled WF sera (from 10 rats; 30-100 day-old) and reacted with sera from 75-day-old (anti-38 kD antibody positive) DP-BB rats. An equal amount $(80 \mu \mathrm{l})$ of bound immune complex was applied to each lane. Molecular weight markers are indicated at left. Antigens of $38 \mathrm{kD}$ and $64 \mathrm{kD}$ are indicated by an arrow with appropriate number at right. lane 1 , lane 2 , and lane 4: L-929 cells, rat pituitary cell line GH3, and normal rat lymphocytes fail to show $38 \mathrm{kD}$ protein band. Lane 3: RINm5F cell shows consistent $38 \mathrm{kD}$ protein band

in these animals may be due to the preservation of intact target antigen on the Beta cells. In contrast, sera from silicatreated WF rats did not show the $38 \mathrm{kD}$ autoantibody as was the case in untreated WF animals. This suggests that the selective preservation of anti-38 $\mathrm{kD}$ islet cell antibody in the sera from silica-treated DP-BB rats is not due to an artifact induced by the administration of silica. The anti$38 \mathrm{kD}$ antibody was not detected in the sera from either Lewis ( 0 of 6 ) or Sprague-Dawley ( 0 of 6 ) rats.

We tested cell-type specificity of the response to anti$38 \mathrm{kD}$ antibody using two established cell lines, mouse fibroblasts (L-929 cells) and rat pituitary cells (GH3), and normal rat lymphocytes obtained from WF rats. L-929 cell (Fig. 3, lane 1), GH3 cell (Fig. 3, lane 2) or rat lymphocyte (Fig.3, lane 4) lysates did not have a $38 \mathrm{kD}$ protein recognized by DP-BB ratsera, whereas RINm5F celllysatesconsistently showed the $38 \mathrm{kD}$ protein band(Fig.3, lane 3). We similarly tested tissue specificity of the response to anti$38 \mathrm{kD}$ antibody using kidney, heart and liver from WF rats. None of the tested tissues showed a $38 \mathrm{kD}$ protein recognized by DP-BB rat sera, while pancreatic islets consistently showed a positive response (data not shown).

We modified the conventional Western blotting method in order to reduce the high background obtained from normal WF rats and diabetic BB rats. The treatment of total RINm5F cell-protein blots with control WF rat sera and, subsequently, with non-labelled second antibody greatly reduced the background and facilitated the detection of specific bands. Using the modified method, i. e. differential Western blotting, the anti-38 kD antibody was also detected in the sera from DP-BB rats (Fig. 4, lane 2), but was not detected in the age-matched control WF sera (Fig. 4, lane 1). Some other bands, which did appear using the immunoprecipitation method (Fig.2), were not detected by Western blotting (Fig.4). Other bands $(45 \mathrm{kD}, 50 \mathrm{kD}$ and $68 \mathrm{kD})$ were present in both control WF and DP-BB rat sera. In contrast, the $38 \mathrm{kD}$ band was consistently detected in only DP-BB rats, excluding neonates (5-day-old BB rats), by both methods. This indicates that the antigenic nature of the $38 \mathrm{kD}$ protein of RINm5F cells was not altered by the denaturing procedure prior to antigen-antibody binding in the differential Western blotting method. With this method, $90 \%$ (10 of 11 ) of DP-BB rats showed the anti-38 kD islet cell autoantibody, while $0 \%$ ( 0 of 7$)$ of age-matched WF rats had such an antibody $(p<0.001)$. To distinguish unequivocally the different patterns of protein bands between WF rat sera and DP-BB rat sera, we compared five individual WF control sera side-by-side with five individual DP-BB rat sera using $20 \mu \mathrm{g}$ of RINm5F cell protein. The anti-38 kD antibody was detected only in the sera from DP-BB rats. We observed exactly the same pattern as shown in Figure 4.

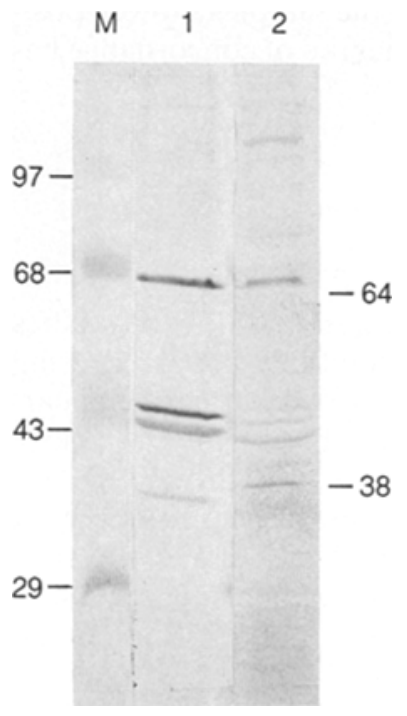

Fig.4. Differential Western blotting of RINm5F cell lysates with sera from the control WF rat and DP-BB rats. RINm5F cell proteins (20 $\mathrm{g} / \mathrm{lane}$ ) were electrophoresed and transferred to nitrocellulose sheets. Each strip was blocked with $3 \%$ bovine serum albumin for $2 \mathrm{~h}$ at room temperature and with pooled control WF rat sera $(1: 100$ dilution) as described in Materials and methods (differential Western blotting). The strips were then incubated with equal amounts (1:100 dilution) of sera from individual WF (75-day-old) (lane 1) and age-matched DP-BB rats (lane 2). Molecular weight markers are indicated at left $(M)$. Antigens of 38 kilodalton $(\mathrm{kD})$ and $64 \mathrm{kD}$ are indicated by an arrow with appropriate number at right. Lane 1: sera from the 75-day-old WF control rat failed to react with $38 \mathrm{kD}$ protein from RINm5F cells. Lane 2: sera from age-matched DP-BB rats reacted with the $38 \mathrm{kD}$ protein 


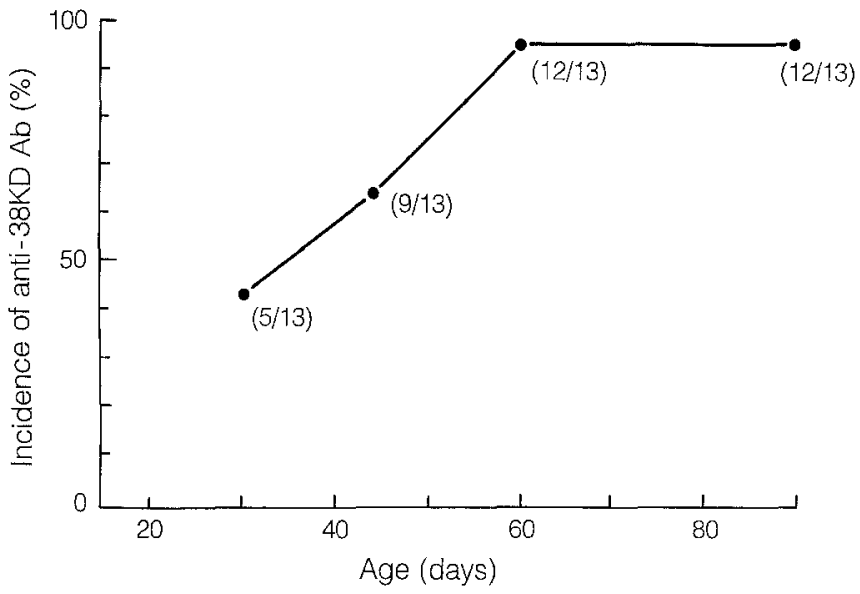

Fig.5. Cumulative incidence of autoantibodies to a 38 kilodalton $(\mathrm{kD})$ islet cell protein in DP-BB rats of different ages. Thirteen DPBB rats were subjected to follow-up studies to determine the incidence of anti- $38 \mathrm{kD}$ islet cell autoantibodies by immunoprecipitation. At around 30, 45, and 60 days of age, 5, 9, and 12 rats respectively had anti-38 $\mathrm{kD}$ islet cell autoantibodies

To determine the degree of concordance between the two methods used, immunoprecipitation and differential Western blotting, we selected ten individual DP-BB rat sera which were positive for anti-38 $\mathrm{kD}$ antibody by the differential Western blotting method. We tested these samples to determine how many were positive for anti$38 \mathrm{kD}$ antibody by the immunoprecipitation method. In this particular experiment, all of the samples showed positive results, indicating that the degree of concordance between the two methods was $100 \%$.

\section{Prediction of diabetes by autoantibody to a $38 \mathrm{kD}$ islet cell protein}

Thirteen DP-BB rats were subjected to follow-up studies to determine when anti-38 kD antibody appeared using the immunoprecipitation method. The time of appearance varied from animal to animal (Fig.5). Five of 13 DP$\mathrm{BB}$ rats $(38 \%)$ had anti- $38 \mathrm{kD}$ antibody at around 30 days of age. An additional four animals had the antibody at around 45 days of age. At about 60 days of age, the antibody was detected in a further three animals. The cumulative incidence of anti- $38 \mathrm{kD}$ antibody in DP-BB rats at the age of 90 days was approximately $92 \%$.

To determine whether an autoantibody to a $38 \mathrm{kD}$ rat islet cell antigen precedes the clinical onset of Type 1 diabetes in $\mathrm{BB}$ rats, we performed follow-up studies on 12 selected DP-BB rats which had the anti-38 kD islet cell antibody. Eleven of 12 DP-BB rats $(91.6 \%)$ which had anti-38 kD islet cell antibody developed diabetes within 60 days ( 40 to 60 days after the detection of the antibody). In contrast, only one of 15 DP-BB rats $(6 \%)$ (12 rats from the colony used for this experiment and three from a routinely maintained colony) which did not contain the antibody developed Type 1 diabetes by the age of 140 days. There is a significant difference in the incidence of diabetes between these groups $(p<0.001)$. These results indicate that an anti-38 kD islet cell autoantibody precedes the clinical onset of Type 1 diabetes in $\mathrm{BB}$ rats.

\section{Correlation between the detection of anti-38 kD islet cell antibody and the presence of pancreatic Beta cells}

At the age of 30 days, the earliest time at which the antibody to a $38 \mathrm{kD}$ islet cell protein was detected, 35 sections of pancreas prepared from five DP-BB rats were examined. All islets showed no insulitis. Similarly, 48 pancreatic sections from six silica-treated adult DP-BB rats which contained anti-38 $\mathrm{kD}$ islet cell antibody revealed intact islet morphology with no lymphocytic infiltration. When the sections from the above two groups were stained with anti-insulin antibody, most islets revealed positive staining for insulin. In contrast, 39 sections from five diabetic $\mathrm{BB}$ rats, which did not contain antibody to a $38 \mathrm{kD}$ islet cell protein, revealed end-stage insulitis, and necrosis of most Beta cells was evident. Only some islets showed mononuclear cell infiltration surrounding a small nest of residual islets. When these pancreatic sections were stained with anti-insulin antibody, most islets revealed negative staining for insulin.

\section{Discussion}

In the present study, we have identified for the first time an autoantibody against a rat islet cell-protein of $38 \mathrm{kD}$ in the sera of DP-BB rats by both immunoprecipitation and differential Western blotting methods, and have found that over $90 \%$ of DP-BB rats in which the antibody was detected, eventually developed Type 1 diabetes. The antibody appeared at around 30 days of age but disappeared within two weeks after diabetes onset. However, the antibody remained in the sera of DP-BB rats which had received silica treatment to prevent the destruction of Beta cells. Our recent experimental results revealed that anti$38 \mathrm{kD}$ autoantibody-positive sera from DP-BB rats did not immunoprecipitate protein from neonate DP-BB islets, but did immunoprecipitate islet cell proteins from adult DP-BB rats which had received silica treatment to prevent insulitis, suggesting that the islet cell specific $38 \mathrm{kD}$ autoantigen was not expressed early in the life of DP-BB rats, but was expressed at around 30 days of age [20]. This might be one reason why young DP-BB rats (less than 30-days-old) did not contain the autoantibody to $38 \mathrm{kD}$ islet cell protein. In contrast to the islet cell specific $38 \mathrm{kD}$ autoantigen, $64 \mathrm{kD}$ autoantigen was expressed on both neonate and adult DP-BB rat islets [20]. It is not yet known if this $38 \mathrm{kD}$ islet cell specific autoantigen is truly involved in the triggering of islet cell specific autoimmunity. However, this antigen is the only delayed-expressed antigen found in DP-BB rats thus far. Therefore, we may speculate that the $38 \mathrm{kD}$ islet cell specific antigen is a candidate for an antigen which may play an important role in the triggering of the autoimmune destruction of Beta cells.

Our recent experimental results showed that pancreatic or islet grafts from neonatal DP-BB rats remained in- 
tact without insulitis when transplanted into acutely diabetic BB rats. In contrast, islet grafts from adult DP$\mathrm{BB}$ rats, which had been treated with silica to preserve islets, were rapidly destroyed in diabetic recipients [21]. These results indicate that neonatal DP-BB rat Beta cells are antigenically different from adult DP-BB rat Beta cells, at least regarding their recognition by immunological effectors. Thus, the selective survival of neonatal DP$\mathrm{BB}$ rat islet grafts in diabetic $\mathrm{BB}$ rats in the study strongly suggests that a putative Beta-cell specific autoantigen might be absent in the neonatal BB rat Beta cells. The induction of self-tolerance cannot occur if certain Beta-cell specific autoantigens do not express early in life. Delayed expression of the antigen later in life would lead to autoimmunity. Adams et al. showed, in several lines of transgenic mice, that the delayed expression of a transgenic self antigen resulted in a failure to establish self-tolerance, and consequently produced autoimmune lesions. In contrast, mice that expressed the transgene early in life were tolerant [22].

In a previous study, autoantibodies in four of four tested newly onset Type 1 diabetic patients immunoprecipitated a $38 \mathrm{kD}$ islet cell protein prepared from HLADR3-positive donor islets [6]. Whether islet cells from HLA-DR3-positive individuals contain a unique antigen recognized by sera from diabetic children has not been determined [6]. Furthermore, the correlation between human diabetic $38 \mathrm{kD}$ antibody and $\mathrm{BB}$ rat $38 \mathrm{kD}$ antibody is unknown. Whether there is any common antigenic determinant between human $38 \mathrm{kD}$ islet cell antigen and rat $38 \mathrm{kD}$ islet cell antigen in the recognition of diabetic sera from humans and $\mathrm{BB}$ rats remains to be elucidated.

To date, no information is available on the presence of an anti-38 kD islet cell autoantibody in BB rats. It is not clear why this antibody, detected consistently in our laboratory, was not mentioned in the previous study [8]. However, several possible explanations exist. First, there may have been many subtle differences in the techniques used in the previous study, even if the same or a similar method was used. The immunoprecipitation method involves several variable factors which may result in a subtly different outcome. These factors are: the antigen preparation procedure (i.e. type of detergent, duration of detergent treatment, condition of cell lysis), the concentration of immunoglobulins in the sample (sera), the washing steps, the type of buffer, and the properties of the protein A sepharose CL-4B. A second possibility is genetic variation among the rats used by the different laboratories. Finally, different diets given to the rats in the different laboratories, or different environmental factors such as bacterial or viral infections may influence the expression of certain islet cell autoantigens, and the production of autoantibodies against the antigens. Among the several possibilities suggested above, subtle differences in the techniques used is the most likely reason for the different observations. In any case, in our studies, we consistently found an islet cell specific autoantibody, against a $38 \mathrm{kD}$ protein, which precedes the clinical onset of diabetes in $\mathrm{BB}$ rats.

Anti-38 kD autoantibodies appear to be an important step toward gaining an understanding of the pathogenesis of Type 1 diabetes, since they precede the onset of spontaneous diabetes. However, the nature of primary islet cell target autoantigen(s) with which the autoantibodies react remains largely unclear. Practically, the islet autoantigen(s) has been difficult to study since (a) the preparation of pure Beta cells from pancreata is not feasible and (b) the preparation of a sufficient amount of islets for appropriate study is difficult. Fortunately, the anti-38 kD antibody which reacted with rat islet cell protein also reacted well with rat insulinoma (RINm5F) cell protein. Although these proteins may not be identical, the portion of cross-reactivity between them would be of great advantage in the study of the nature of the $38 \mathrm{kD}$ autoantigen at the molecular level. Therefore, identification of the anti$38 \mathrm{kD}$ islet cell autoantibody, which cross-reacts with a rat insulinoma cell protein of $38 \mathrm{kD}$ and precedes the onset of Type 1 diabetes in $\mathrm{BB}$ rats, will be invaluable for study of the molecular nature of the target islet cell autoantigens associated with the induction of autoimmunity in DP-BB rats.

Acknowledgements. We are very grateful to Dr. M. Hollenberg for his stimulating discussions. Also, we gratefully acknowledge the editorial help of Mrs. K. Clarke and the secretarial help of Mrs. L. Pearson. This work was supported by grant MA9584 from Medical Research Council of Canada to J. W.Y. and Julia McFarlane Diabetes Research Centre. J. W. Yoon is a Heritage Medical Scientist Awardee of the Alberta Heritage Foundation for Medical Research, and S.H.I. is a Postdoctoral Fellowship Awardee of the Canadian Diabetes Association. I. Y.K. is a Graduate Assistantship Awardee of the University of Calgary.

\section{References}

1. Gorsuch AN, Spencer KN, Lister J et al. (1981) Evidence for a long prediabetic period in type I (insulin-dependent) diabetes. Lancet II: $1363-1365$

2. Eisenbarth G (1986) Insulin dependent diabetes mellitus: a chronic autoimmune disease. N Engl J Med 314: 1360-1368

3. Cahill GF, McDevitt HO (1981) Insulin-dependent diabetes mellitus: the initial lesion. N Engl J Med 304: 1454-1455

4. Lernmark $\AA$, Baekkeskov S (1981) Islet cell antibodies: theoretical and practical implications. Diabetologia 21:431-435

5. Rossini AA, Mordes JP, Like AA (1985) Immunology of insulindependent diabetes mellitus. Ann Rev Immunol 3: 289-320

6. Baekkeskov S, Nielsen JH, Marner B, Bilde T, Ludvigsson J, Lernmark A (1982) Autoantibodies in newly diagnosed diabetic children immunoprecipitate human pancreatic islet cell proteins. Nature 298: 167-169

7. Backkeskov S, Landin M, Kristensen JK et al. (1987) Antibodies to a $64000 \mathrm{Mr}$ human islet cell antigen precede the clinical onset of insulin-dependent diabetes. J Clin Invest 79: 926-934

8. Baekkeskov S, Dyrberg T, Lernmark $\AA$ (1984) Antibodies to a $64 \mathrm{kD}$ islet cell protein precede the onset of spontaneous diabetes in the BB rat. Science 224: 1348-1350

9. Holmes L, Laskowska P, Atkinson MA (1990) Evidence against glycosylation and surface expression of the Mr $64000(64 \mathrm{~K})$ islet cell autoantigen. Diabetes 39 [Suppl. 1]: 70 (Abstract)

10. Lee KU, Kim MK, Amano K et al. (1988) Preferential infiltration of macrophages during early stages of insulitis in diabetes prone BB rats. Diabetes 37: 1053-1058

11. Lee KU, Pak CY, Amano K, Yoon JW (1988) Prevention of lymphocytic thyroiditis and insulitis in diabetes prone $\mathrm{BB}$ rats by the depletion of macrophages. Diabetologia 31: 400-402

12. Amano K, Yoon JW (1990) Studies on autoimmunity for the initiation of Beta-cell destruction: V. decrease of macrophage- 
dependent $\mathrm{T}$ lymphocytes and NK cytotoxicity in silica-treated DP-BB rats. Diabetes 39: 590-596

13. Bae YS, Eun HM, Yoon JW (1989) Molecular identification of diabetogenic viral gene. Diabetes 38: 316-320

14. Koevary SB, Williams DE, Williams RM, Chick WL (1985) Passive transfer of diabetes from BB/W to Wistar-Furth rats. J Clin Invest 75: 1904-1907

15. Yoon JW, Notkins AL (1976) Virus-induced Diabetes Mellitus VI. Genetically determined host differences in the replication of encephalomyocarditis virus in pancreatic Beta cells. J Exp Med 143: $170-185$

16. Sutton R, Peter M, McShane P, Gray DWR, Morris PJ (1986) Isolation of rat pancreatic islets by ductal injection of collagenase. Transplantation 42: 689-691

17. Ko IY, Park SS, Song BJ et al. (1987) Monoclonal antibodies to ethanol-induced rat liver cytochrome P-450 that metabolizes aniline and nitrosamines. Cancer Res 47: 3101-3109

18. Yoon JW, Bachurski CJ, Shin SY, Archer J (1984) Isolation, cultivation and characterization of murine pancreatic Beta cells in microculture system. In: Pohl SL, Larner J (eds), Methods in diabetes, Vol. 1. John Wiley and Sons, New York. pp 173-184

19. Sokal RR, RohIf FS (1969) Biometry: the principles and practice of statistics in biological research. Freeman, San Francisco
20. Ko IY, Yoon. JW (1991) Delayed expression of islet cell specific autoantigen in $\mathrm{BB}$ rats may be responsible for the initiation of autoimmune Type 1 diabetes. Diabetes 40 [Suppl 1]: $54 \mathrm{~A}$

21. Ihm SH, Lee KU, Yoon JW (1990) Studies on autoimmunity for the initiation of Beta-cell destruction. VII. Evidence for antigenic changes on the Beta-cells leading to the autoimmune destruction of Beta cells in BB rats. Diabetes 40: 269-274

22. Adams TE, Alpert S, Hanahan D (1987) Non-tolerance and autoantibodies to a transgenic self antigen expressed in pancreatic Beta-cells. Nature 325:223-228

Received: 16 November 1990

and in final revised form:23 April 1991

\section{Dr. J.-W. Yoon}

Julia McFarlane Diabetes Research Centre

Faculty of Medicine

The University of Calgary

3330 Hospital Drive NW

Calgary, Alberta T2N 4N1

Canada 